\title{
Differing acute phase responses in Crohn's disease and ulcerative colitis
}

\author{
S H SAVERYMUTTU, H J F HODGSON, V S CHADWICK AND M B PEPYS \\ From the Gastroenterology Unit and MRC Acute Phase Protein Research Group, Immunological Medicine \\ Unit, Department of Medicine, Royal Postgraduate Medical School, Hammersmith Hospital, London
}

SUMmaRY Thirty eight patients with Crohn's disease and 30 patients with ulcerative colitis have been assessed using the technique of faecal excretion of ${ }^{111}$ Indium granulocytes to quantify precisely acute inflammatory activity. At the time of each faecal granulocyte measurement the serum concentration of the acute phase protein C-reactive protein and the erythrocyte sedimentation rate were estimated. C-reactive protein concentration was significantly higher in Crohn's disease than ulcerative colitis both overall and particularly in relation to given levels of granulocyte excretion. No such distinction was observed between the erythrocyte sedimentation rates in the two diseases. The present findings show that the acute phase response differs significantly between Crohn's disease and ulcerative colitis. Patients with ulcerative colitis may be constitutionally different from those with Crohn's disease and unable to mount a major acute phase response to their own disease.

Crohn's disease and ulcerative colitis are inflammatory conditions of unknown aetiology, with an unpredictable natural history. They pose problems both in assessment of disease activity and in treatment. In most cases there is a clear distinction between the two conditions on clinical and pathological grounds but in up to $10 \%$ of patients it may not be possible to differentiate between them. ${ }^{1}$ It has even been suggested that Crohn's disease and ulcerative colitis are polar extremes of a single disease entity. ${ }^{2}$

There is no haematological or serological abnormality which is specific for either Crohn's disease or ulcerative colitis and the most widely used nonspecific index of inflammatory activity, the erythrocyte sedimentation rate, is raised to a similar extent in both conditions. The serum concentrations of the acute phase proteins C-reactive $\operatorname{protein}^{34}$ and serum amyloid A protein, ${ }^{5}$ however, are significantly higher in Crohn's disease than they are in ulcerative colitis for given degrees of clinical disease activity.

The difficulty in clinical assessment of activity in

Address for correspondence: Dr S H Saverymuttu, Medicine II, St George's Hospital Medical School, Cranmer Terrace, Tooting, London SW17.

Received for publication 4 November 1985. inflammatory bowel disease is well recognised: the pathology is largely inaccessible to direct observation and there is often a discrepancy between clinical manifestations and histological abnormality in biopsies, which must necessarily be small and therefore subject to sampling error. The technique of measurement of the intestinal excretion of ${ }^{111} \mathrm{In}$ labelled autologous granulocytes ${ }^{6}$ is a major advance in objective monitoring of patients with inflammatory bowel disease. This approach provides a direct and precisely quantitative assay of one of the major components of the acute inflammatory process in the target organ. It correlates very well with what have hitherto been the best available means for assessing activity of inflammatory bowel disease in both Crohn's disease and ulcerative colitis.

We report here a prospective, correlative study in which faecal granulocyte excretion and serum Creactive protein concentration were measured in parallel. The results confirm that for any given level of inflammation, as reflected in the granulocyte excretion, the serum C-reactive protein values were significantly higher in Crohn's disease than in ulcerative colitis. Our findings may have important implications for the empirical clinical application of these tests and also for more fundamental understanding of pathogenetic mechanisms. 


\section{Methods}

PATIENTS

Thirty eight patients with Crohn's disease and 30 with ulcerative colitis were each studied on up to three occasions. Each individual study was analysed separately.

\section{INVESTIGATIONS}

Serum C-reactive protein concentrations were measured by electroimmunoassay ${ }^{4}$ in samples which had been stored at $-20^{\circ} \mathrm{C}$. The sensitivity of the assay was $2 \mathrm{mg} / \mathrm{l}$. Among 468 normal volunteer blood donors the concentration was less than $10 \mathrm{mg} / \mathrm{l}$ in $99 \%$ and less than $3 \mathrm{mg} / \mathrm{l}$ in $90 \% .^{7}$ On the same day on which serum was taken for C-reactive protein estimation, autologous granulocytes were labelled and separated as previously described. ${ }^{6}$ After reinjection of the labelled cells $(150-350 \mu \mathrm{Ci})$ a four day faecal collection was made and the total ${ }^{111}$ In content measured and expressed as a percentage of the injected dose. On the basis of the faecal granulocyte excretion measurement the results in each individual patient were divided into three groups: group 1, excretion 0-15\%; group 2, excretion $15-30 \%$; group 3 , excretion greater than $30 \%$.

\section{STATISTICS}

Differences between disease groups were analysed using the Wilcoxon's rank sum test.

\section{PATIENTS STUDIED}

The clinical details are summarised in the Table. A total of 57 studies were carried out on 38 patients with Crohn's disease and 41 studies on 30 patients with ulcerative colitis between September 1981 and September 1983. These were consecutive patients

Table Clinical details of patients

\begin{tabular}{lll}
\hline & $\begin{array}{l}\text { Crohn's } \\
\text { disease }\end{array}$ & $\begin{array}{l}\text { Ulcerative } \\
\text { colitis }\end{array}$ \\
\hline Patients (no) & 38 & 30 \\
Studies (no) & 57 & 41 \\
Age range (years) & $16-69$ & $15-66$ \\
Sex & M 15:F 23 & M 14:F 16 \\
Disease distribution: & 3 & \\
$\quad$ Whole colon & 1 & 10 \\
Rectum to hepatic flexure & 0 & 7 \\
$\quad$ Rectum to splenic flexure & 2 & 9 \\
Recto sigmoid & & 4 \\
Ascending, transverse & 4 & 0 \\
$\quad$ and descending colon & 3 & 0 \\
Other colonic distribution & 5 & 0 \\
Ileocolonic & 14 & 0 \\
Ileal disease & 6 & \\
Ileal resection & & \\
\hline
\end{tabular}

attending the Gastroenterology Unit at Hammersmith Hospital and no selection criteria were applied other than the exclusions noted below. The diagnosis in all cases had been established by standard clinical, radiological, and histopathological features. ${ }^{8-10}$ Patients with active extra-intestinal complications or bacterial infection were excluded from the study. Patients treated with steroids were excluded from the study because it is not known whether steroids have differential effects on serum $C$-reactive protein concentrations and faecal granulocyte excretion.

\section{Results}

\section{FAECAL GRANULOCYTE EXCRETION}

The normal faecal granulocyte excretion was established in 20 patients with the irritable bowel syndrome and ranged from $0.3 \%$ to $1.9 \%$ (mean $\pm S D$, $1 \cdot 2 \% \pm 0 \cdot 5 \%)$. In patients with Crohn's disease faecal granulocyte excretion ranged from $0.6 \%$ to $61 \%$ and in ulcerative colitis from $0.5 \%$ to $58.5 \%$. Three patients with Crohn's disease and six patients with ulcerative colitis had faecal excretion rates within the normal range, that is less than $2 \%$. Thirty two studies in Crohn's disease and 21 studies in ulcerative colitis were included in group 1, 14 studies in Crohn's disease and 11 studies in ulcerative colitis were in group 2 and 11 studies in Crohn's disease with nine studies in ulcerative colitis in group 3 (Fig. 1).

\section{SERUM C-REACTIVE PROTEIN CONCENTRATIONS} In 20 patients with the irritable bowel syndrome serum C-reactive protein was undetectable $(<2$ $\mathrm{mg} / \mathrm{l})$. The serum C-reactive protein concentration was between $<2-196 \mathrm{mg} / \mathrm{l}$ in Crohn's disease and $<2-54 \mathrm{mg} / \mathrm{l}$ in ulcerative colitis (Fig. 1). In Crohn's disease CRP was raised in 22 studies in group 1 and in all patients in groups 2 and 3. All three Crohn's disease patients and the six ulcerative colitis patients with granulocyte excretion less than $2 \%$ had Creactive protein concentrations less than $2 \mathrm{mg} / \mathrm{l}$. Although there was a trend towards higher $\mathrm{C}$-reactive protein concentrations with greater granulocyte excretion only the difference between group 1 and group 2 was statistically significant $(p<0.01)$. In serial studies of individual patients, the serum C-reactive protein concentration always changed in the same direction as changes in the faecal granulocyte excretion. There was no difference in C-reactive protein concentrations between small and large bowel Crohn's disease $(p>0.05)$. In contrast with Crohn's disease, patients with ulcerative colitis had only modest rises of their serum Creactive protein concentrations. The $\mathrm{C}$-reactive 


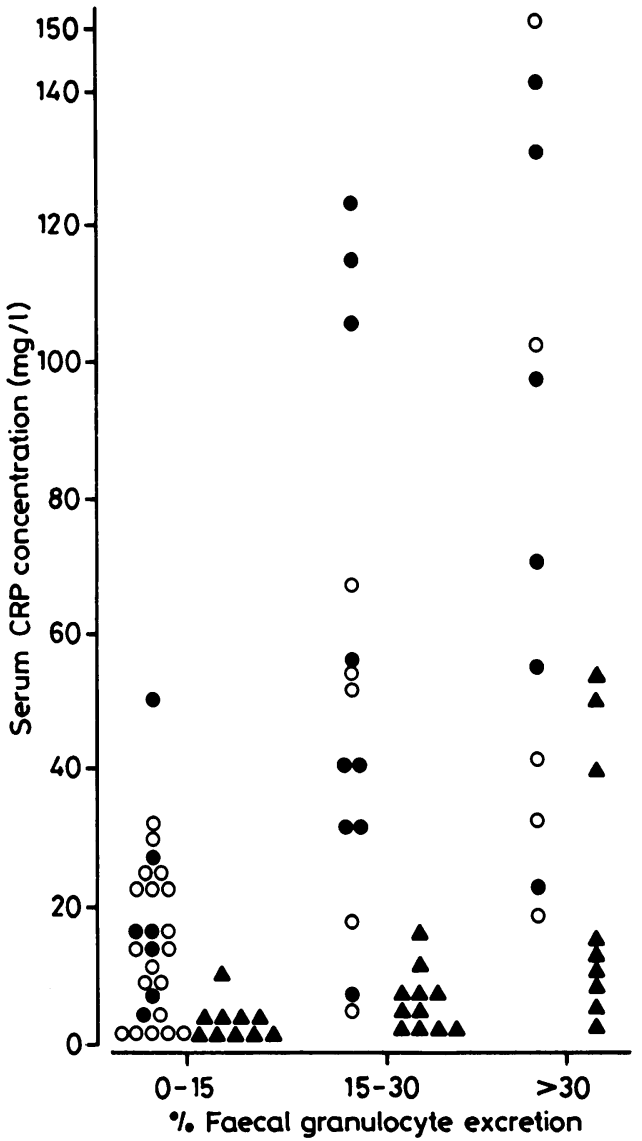

Fig. 1 Serum CRP concentration in individual studies on (ileo) colitis (O), Crohn's ileitis (O) and ulcerative colitis (A) for three ranges of faecal granulocyte excretion.

protein concentrations in all three groups were significantly lower than in Crohn's disease $(p<0 \cdot 001)$. This difference remained when just Crohn's colitis was analysed. Only three patients with ulcerative colitis had C-reactive protein concentrations greater than $20 \mathrm{mg} / \mathrm{l}$ and all were studied when they were febrile. None, however, had a documented infection.

ESR VALUES IN CROHN'S DISEASE AND ULCERATIVE COLITIS

There was no significant difference between the ESR values in Crohn's disease and ulcerative colitis in any of the three groups (Fig. 2).

\section{Discussion}

We confirm here that the serum concentration of Creactive protein is raised in patients with active

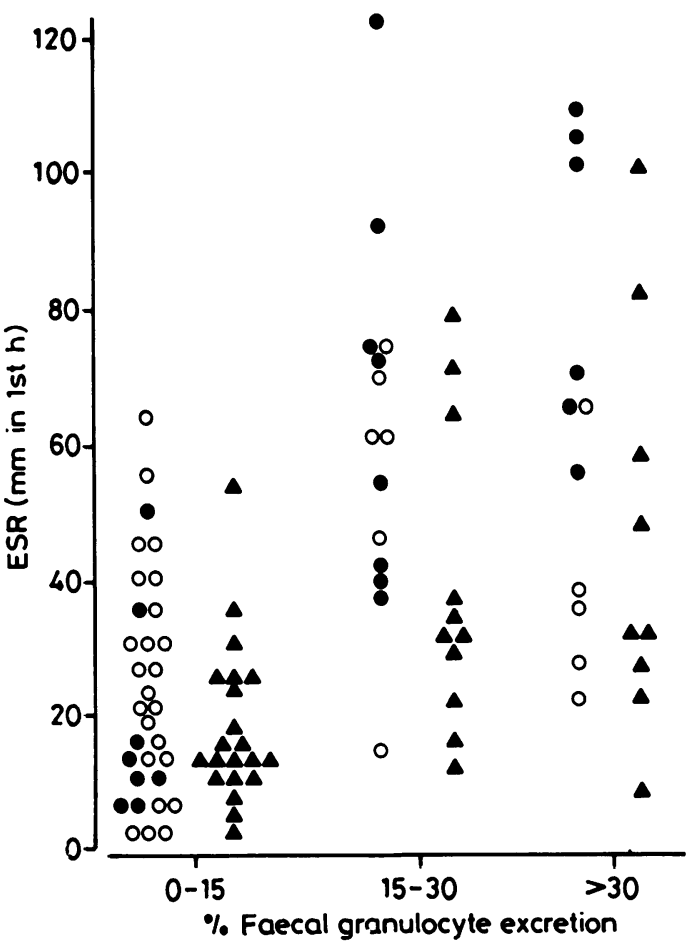

Fig. 2 ESR in individual studies in Crohn's (ileo) colitis (O), Crohn's ileitis $(\mathrm{O})$ and ulcerative colitis ( $(\mathbf{\Delta})$ for three ranges of faecal granulocyte excretion.

Crohn's disease and that it is significantly greater than in patients with active ulcerative colitis. Activity was assessed by measurement of the faecal excretion of labelled granulocytes, which has previously been shown to correlate closely with other laboratory tests for activity in inflammatory bowel disease. ${ }^{6}$

The precise significance of passage of granulocytes into the intestinal tract and their excretion in the faeces is not known. These cells are, however, a major component of the acute inflammatory response in both Crohn's disease and ulcerative colitis and are equipped, particularly by virtue of their content of lysosomal enzymes, to be important mediators of tissue damage. Levels of faecal granulocyte excretion may therefore closely reflect the extent of tissue damaging inflammatory activity in the lesions. On the other hand shedding of granulocytes from sites of ulceration or even through intact epithelium ${ }^{11}$ may be a more indirect index of the primary pathology. These possibilities are not the only ones nor are they mutually exclusive, but whatever the underlying mechanisms the quantification of faecal granulocyte excretion is certainly the most direct approach so far to a global 
assessment of the intensity of acute inflammation throughout the intestine.

Given that this is the case the striking difference in C-reactive protein response between ulcerative colitis and Crohn's disease remains unexplained. $\mathrm{C}$-reactive protein, serum amyloid $\mathrm{A}$ protein and most of the other acute phase proteins are synthesised de novo by hepatocytes in response to most forms of tissue damage, infection and inflammation. ${ }^{12}$ The triggering mechanisms by which these stimuli initiate acute phase protein synthesis are incompletely understood but there is experimental evidence indicating that interleukin 1 (IL1) may be involved. Interleukin 1 is a $10-15 \mathrm{kd}$ peptide, or family of closely related peptides, which is synthesised and secreted by activated macrophages. ${ }^{13}$ In addition to its capacity to initiate acute phase protein production by the liver, IL1 also causes fever (endogenous pyrogen) and promotes lymphocyte activation. IL1 synthesis can be induced directly by various chemicals (phorbol myristate acetate) or microbial products (lipopolysaccharide, muramyl dipeptide) and also by the products of activated $T$ cells. Granulocytes themselves seem not to be involved in IL1 production or to play any necessary role in induction of the acute phase response. ${ }^{14}$

The difference in acute phase response to Crohn's disease and ulcerative colitis may thus reflect their different pathology, and certainly in typical Crohn's lesions there is always a major mononuclear cell component (lymphocytes and macrophages) even though there may also be an abundance of polymorphonuclear cells. In contrast the histopathology of typical ulcerative colitis is characterised by an almost exclusively granulocyte infiltration. There are, however, many conditions in which the histology shows only acute, polymorph infiltration in which high C-reactive protein values are seen, for example acute bacterial infection and acute ischaemic tissue necrosis. ${ }^{12}$ Whilst it is possible that here the macrophages are being stimulated directly by bacterial products or by material from damaged autologous cells, it is difficult to see why similar stimulation should not occur in patients with ulcerative colitis. One explanation might be that such patients are in some way constitutionally different from those with Crohn's disease and are unable to mount a major acute phase response to their own disease, even though they can do so to other stimuli such as major bacterial infection or surgery.

The possible mechanisms for this hypothetical low responder state can only be speculative at present and may involve lack of response by macrophages, defective IL1 production, poor response by hepatocytes, etc. Patients with systemic lupus erythematosus have an apparently similar defect and produce relatively little or no $\mathrm{C}$-reactive protein in response to their own disease but mount much greater responses to intercurrent microbial infection. ${ }^{15}$ There is evidence from murine models of autoimmune lupus-like disease that these variations in acute phase responder status are genetically determined $^{16}$ but unfortunately no such animal models exist of human inflammatory bowel disease.

We thank Amersham International for supplying ${ }^{111} \mathrm{InCl}_{3}$. SHS was supported by the Wellcome Trust. This study was supported in part by MRC Programme Grant 979/51 to MBP.

\section{References}

1 Price $\mathrm{AB}$. Overlap in the spectrum of non-specific inflammatory bowel disease: colitis indeterminate. $J$ Clin Pathol 1978; 31: 567-77.

2 Hodgson HJF. Non-specific inflammatory bowel disease - one disease or two? In: Allan RN, Keightley MRB, Hawkins C, Alexander-Williams J, eds. Inflammatory bowel disease. Edinburgh: Churchill Livingstone, 1983: 86-93.

3 Pepys MB, Druguet M, Klass HJ, Dash AC, Mirjah DD, Petrie A. Immunological studies in inflammatory bowel disease. In: Knight J, Porter R, eds. Immunology of the gut. Ciba Foundation Symposium 46 (new series). Amsterdam: Elsevier/Excerpta Medica/North Holland, 1977: 283-97.

4 Fagan EA, Dyck RF, Maton PN, Hodgson HJF, Chadwick VS, Pepys MB. Serum levels of C-reactive protein in Crohn's disease and ulcerative colitis. Eur J Clin Invest 1982; 12: 351-60.

5 de Beer FC, Mallya RK, Fagan EA, Lanham JG, Hughes GRV, Pepys MB. Serum amyloid A protein concentration in inflammatory diseases and its relationship to the incidence of reactive systemic amyloidosis. Lancet 1982; ii: 231-4.

6 Saverymuttu SH, Peters AM, Lavender JP, Pepys MB, Hodgson HJF, Chadwick VS. Quantitative fecal indium 111-labeled leukocyte excretion in the assessment of disease in Crohn's disease. Gastroenterology 1983; 85: 1333-9.

7 Shine B, de Beer FC, Pepys MB. Solid phase radioimmunoassays for C-reactive protein. Clin Chim Acta 1981; 117: 13-23.

8 de Dombal FT, Burton IL, Clamp SE, Goligher JC. Short-term course and prognosis of Crohn's disease. Gut 1974; 15: 435-43.

9 Williams HJ, Stephens DH, Carlson HC. Double contrast radiography: colonic inflammatory bowel disease. Am J Radiogr 1981; 137: 315-22.

10 Lockhart-Mummery HE, Morson BC. Crohn's disease (regional enteritis) of the large intestine and its distinction from ulcerative colitis. Gut 1960; 1: 87-105.

11 Bellamy JEC, Nielsen NO. Immune-mediated emigration of neutrophils into the lumen of the small intestine. Infect Immun 1974; 9: 615-19.

12 Pepys MB, Baltz ML. Acute phase proteins with 
special reference to $\mathrm{C}$-reactive protein and related proteins (pentaxins) and serum amyloid A protein. $A d v$ Immunol 1983; 34: 141-212.

13 Dinarello CA. Interleukin 1. Rev Infect Dis 1984; 6: 51-95.

14 Baltz ML, Rogers SL, Gomer K, Davies AJS, Doenhoff MJ, Klaus GGB, Pepys MB. Studies of serum amyloid $\mathrm{P}$ component (SAP) as an acute phase reactant in mice. In: Glenner GG, Pinho e Costa P, Falcao de Freitas F, eds. Amyloid and amyloidosis. Amsterdam: Exerpta Medica, 1980; 534-42.
15 Pepys MB, Lanham JG, de Beer F. C-reactive protein in systemic lupus erythematosus. In: Hughes GRV, ed. Systemic lupus erythematosus. Clinics in the rheumatic diseases. Vol. 8, No. 1. Eastbourne: Saunders, 1982: 91-103.

16 Rordorf C, Schnebli HP, Baltz ML, Tennent GA, Pepys MB. The acute phase response in (NZB $\mathrm{xNZW}) \mathrm{F}_{1}$ and $\mathrm{MRL} / 1$ mice. Contrasting patterns resembling those in human systemic lupus erythematosus and rheumatoid arthritis respectively. $J$ Exp Med 1982; 156: 1268-72. 